\title{
ANALISIS INTRINSIK SIMBOL BUDAYA MELAYU DALAM KARYA CATAN MODEN TERPILIH JALAINI ABU HASSAN DAN FATIMAH CHIK
}

\author{
AHMAD HAKIM ABDULLAH* \\ YUHANIS IBRAHIM** \\ RAJA ISKANDAR RAJA HALID \\ hakimabdullah08@gmail.com/hakim.c18e026f@siswa.umk.edu.my*, \\ yuhanisibrahim@umk.edu,my**,rajaiskandar@umk.edu.my***
}

\begin{abstract}
Abstrak
Kajian ini bertujuan menganalisis skop perkembangan karya-karya seni oleh Jalaini Abu Hassan dan Fatimah Chik melalui pendekatan Edmund Feldman pada tahun 1967 yang menerangkan empat langkah aras kritikal analisis seperti yang berikut iaitu deksripsi, analisis, interpretasi dan pertimbangan. Kerangka kerja teoritikal yang dianalisis menggunakan teori Edmund Feldman yang diasaskan pada tahun 1967 dengan menekankan metodologi analisis kaedah primari iaitu pemerhatian dua karya seni catan iaitu Pohon beringin yang dihasilkan oleh Fatimah Chik pada tahun 2002 dan karya Tales of the heroes yang dihasilkan oleh Jalaini Abu Hassan pada tahun 2010. Nilai kemelayuan juga terdapat pada makna tersurat terutamanya pada catan Pohon beringin Fatimah seperti simbol segi tiga, wayang kulit Kelantan, filem Melayu Bawang Putih Bawang Merah telah diinspirasikan daripada falsafah catan Pohon Beringin itu dan juga tidak dapat dipisahkan dengan simbol warisan Melayu yang telah divisualkan dalam kalangan masyarakat Melayu sejak zaman nenek moyang kita lagi dan sehingga ke zaman era kemodenan abad ke 21 ini. Dapatan kajian dalam catan Jalaini Abu Hassan menunjukkan terdapat seorang lelaki dengan baju melayu menjelaskan tentang 5 prinsip rukun Islam dan rukun negara dan juga makna tersurat tentang perubatan tradisional Islam yang telah diaplikasikan dalam kehidupan Jailani dan ayahnya.
\end{abstract}

Kata kunci: Analisis Intrinsik, Pohon Beringin, Simbol Budaya Melayu 


\title{
AN INSTRINSIC ANALYSIS OF MALAY CULTURAL SYMBOLS IN SELECTED MODERN PAINTING ARTWORKS OF JALAINI ABU HASSAN AND FATIMAH CHIK
}

\author{
AHMAD HAKIM ABDULLAH* \\ YUHANIS IBRAHIM** \\ RAJA ISKANDAR RAJA HALID*** \\ hakimabdullah08@gmail.com/hakim.c18e026f@siswa.umk.edu.my*, \\ yuhanisibrahim@umk.edu,my**, rajaiskandar@umk.edu.my***
}

\begin{abstract}
This paper aims to analyse the development of Malaysian artworks of Jalaini Abu Hassan and Fatimah Chik paintings through the Edmund Feldman 1967 approach which is a theory that describes the description, the analysis, the interpretation and the judgement. The theoretical framework of this approach involved four steps of critical analysis processes. Hence, the methodology emphasized the qualitative methodology by observing two (2) paintings which were Tales of the Heroes from year 2010 and Pohon Beringin from year 2002 artworks by the Malay Malaysian artists, Jalaini Abu Hassan and Fatimah Chik, respectively. The findings suggested that the Malaysian painters expressed the value of the Malay identity and philosophy in their artworks. For example, Jalaini Abu Hassan's Tales of the Heroes that potrayed a guy in Malay's traditional costume represented the 5 Pillars of Islam, the National Principles (Rukun Negara) and the literal meaning of the traditional Islamic medicine which were applied in Jalaini's and his father's lives. Additionally, the Malay value can also be found literally in Pohon Beringin batik painting by Fatimah Chik such as the triangle symbol. To date, banyan tree has a significant meaning in the Malay heritage which have been visualised in the Malay community since the ancestral era. Other than the canvas painting of Fatimah Chik's Pohon Beringin, the banyan tree has been adapted in many Malay artworks such as Kelantanese Wayang Kulit and Malay film of Bawang Putih Bawang Merah.
\end{abstract}

Keywords: Artworks, Fatimah Chik, Intrinsic Analysis, Jalaini Abu Hassan, Malay cultural symbols 
The meaning of Malay or its equivalents, Melayu and Maleis have never been established and they never will be. On the other hand, Malay is a fraught term. In this paper, the definitions of Malay focus on Malay as an identity marker of the people who meet the criteria to be categorized as such. One of the definitions is the one provided by Dewan Bahasa dan Pustaka (the main organization of Malay language in Malaysia) and the United Nations that refer Malays as the aboriginal residents that speak Malay, practice Malay tradition and custom, as well as Islamic teachings. They are also under the sultanate rulling with a privilege status in Malaysia (Amin \& Rahman,2013).

The existence of the Malay cultural symbols serves to be the effort of the local artists in the search for paintings identity. It also involves the creation of artworks using the ideas that have gone through past experiences and passed on artworks in the cultural context of Malay heritage. Changes in producing artworks are constantly shifting according to the wishes of the art enthusiasts and the timeline (Abdul Malek,2019).

Nowadays, global development with modernity has huge impact on the thinking style of artists in various fields especially in painting and designing. Therefore, since the force of modernity and the shift of genre painting style, the perception on the Malay heritage also has slowly changed but this heritage value must be preserved for the next generation (Zainuddin, 2020). This is because it is crucial for Malays to preserve their cultural heritage which based on the Islamic teachings that are inseparable in creating the $21^{\text {st }}$ century's modern painting that make huge impact particularly signification aspects of each of these modern art paintings.

This paper addresses three objectives. First, to identify the use of Malay cultures in Jalaini Abu Hassan's and Fatimah Chik's paintings. Second, to investigate the significance of Malay philosophy in Jalaini Abu Hassan's and Fatimah Chik's paintings. Third, to study the philosophy and the meaning behind Jalaini Abu Hassan's and Fatimah Chik's paintings. These are in parallel to four research questions as follows: i) What are the main Malay cultures principles used in the Jalaini Abu Hassan's and Fatimah Chik's paintings? ii) What is the significance of Malay philosophy in the Jalaini Abu Hassan's and Fatimah Chik's paintings? iii) What is the philosophy applied in the Jalaini Abu Hassan's and Fatimah Chik's paintings?

\subsection{Literature Review}

The Malay culture has influenced the behaviour of the people. It contains guidance for people in acting and interacting with others. Furthermore, the Malay culture identities can be found in this archipelago include Keris, and also traditional houses, songs and dances. Unfortunately, the Malay cultural objects are found in different locations and still separated in each area. Additional factor is that some Malay cultural objects have damaged and lost (Wong \& Yousof, 2018). Other than that, in searching framework of the arts identity, artist make an attempt to create Malay cultural symbols, especially with regards to the traditional Malay home interior decorations, wood-carving, folk arts such as Wayang Kulit, traditional music and handicraft are parts of the references that have been introduced by local artists. Art and culture of the Malay community have various contexts with extensive assessment. 
Additionally, the art form of Malay culture have been created by the Malay community itself. This is because they have to prove the civilization of their own communities (Noh et al., 2020). The symbol of Malay culture is the art activity through specific process produced. These include terms of artistic expression involving civilization of the Malay community through films, literatures, traditional dances and cultural activities that convey a preaching oriented message and also give a message or a clear meaning of the current politics while songs are characterized by values that have spiritual content (Ahmad, 2020). This is because the artist has the knowledge and the love towards the beauty of art in addition to the civilization of the Malay culture itself.

\subsection{Methodology}

The data of the study was obtained by conducting research at the library as well as reading journal articles and scholarly books. The researchers also interviewed two selected artists which were Faizal Sidik and Adzran Omar in the field of art painting by issuing them 10 questions related to the value of the Malay symbols in Malaysian paintings. This was followed by the observations of the painters' works at their studio. In addition, the voice recording method was also used to retrieve the needed data from all artists during the interviews.

The study involved several Malaysian artists and academicians. It explained how researchers obtained the painters' artwork data from various sources such as the painters' gallery, the painting museums and the painters' studio. However, the result of the painters' works was also selected using the observation method of each work associated with the Malay value and cultural symbols. This was followed by an observation on the catalogues and the webs which enabled the researchers to be more selective in choosing suitable artworks as the research samples. For sampling purpose, the researchers selected two paintings which were the most significant artworks before analysing them based on the formal elements and the method of art criticism in the meaning of the visual elements. The research also incorporated the qualitative method where the researchers interviewed an academician in his art studio.

\subsection{Theory Method of Art Criticism Critical Processes by Edmund Feldman (1967)}

This study emphasized the qualitative method using the theory from Edmund Feldman for the description, the analysis, the interpretation and the judgement of the artworks. It focused on the external aspects of the artworks by making detailed figures of lines, colours, main subjects, as well as the background of each figure. The method is briefly presented in the diagram below. 


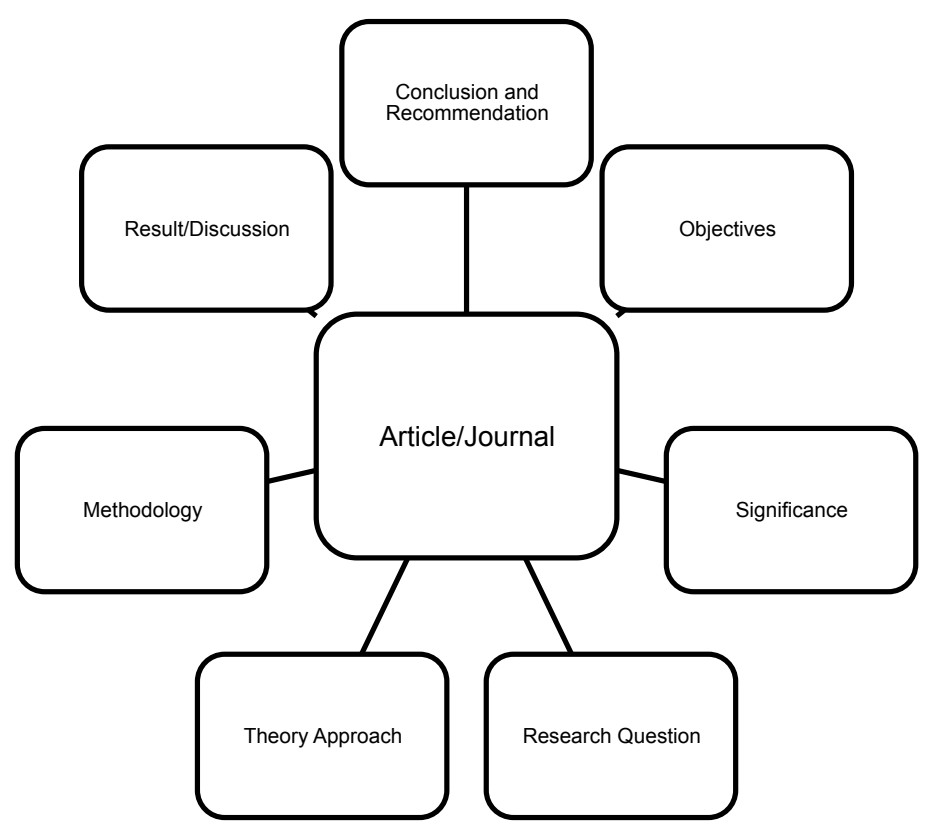

Figure 1: Mind map of Malay cultures research in Malaysian art paintings

The theoretical framework of this analysis was based on the theory by Edmund Feldman (1967) which has four stages structure of criticism which involved description, analysis, interpretation and judgement of an artwork.

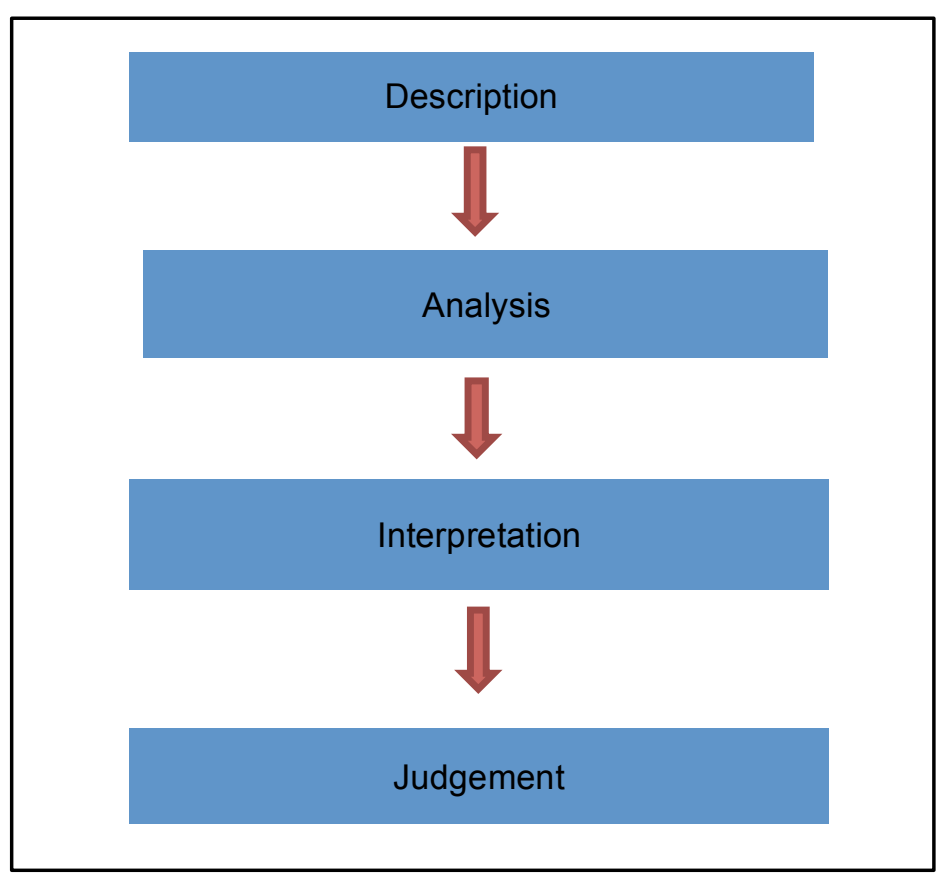

Figure 2: Four stages of the art criticism by Edmund Feldman (1967) (Source: Researcher's collection,2020) 


\subsubsection{Description}

Naming what an observer sees is part of the overall process of description.

\subsubsection{Analysis}

Dealing with visual evidence. It is an advanced type of description.

\subsubsection{Interpretation}

The crucial third stage of art criticism. This is the point at which our search for meaning reached the climax.

\subsubsection{Judgement}

Final stage for evaluation of criticism is the evaluation of whole artworks. The judgement is also a logical and plausible opinion or opinion through the thinking of an art critics.

\subsection{Results and Discussion}

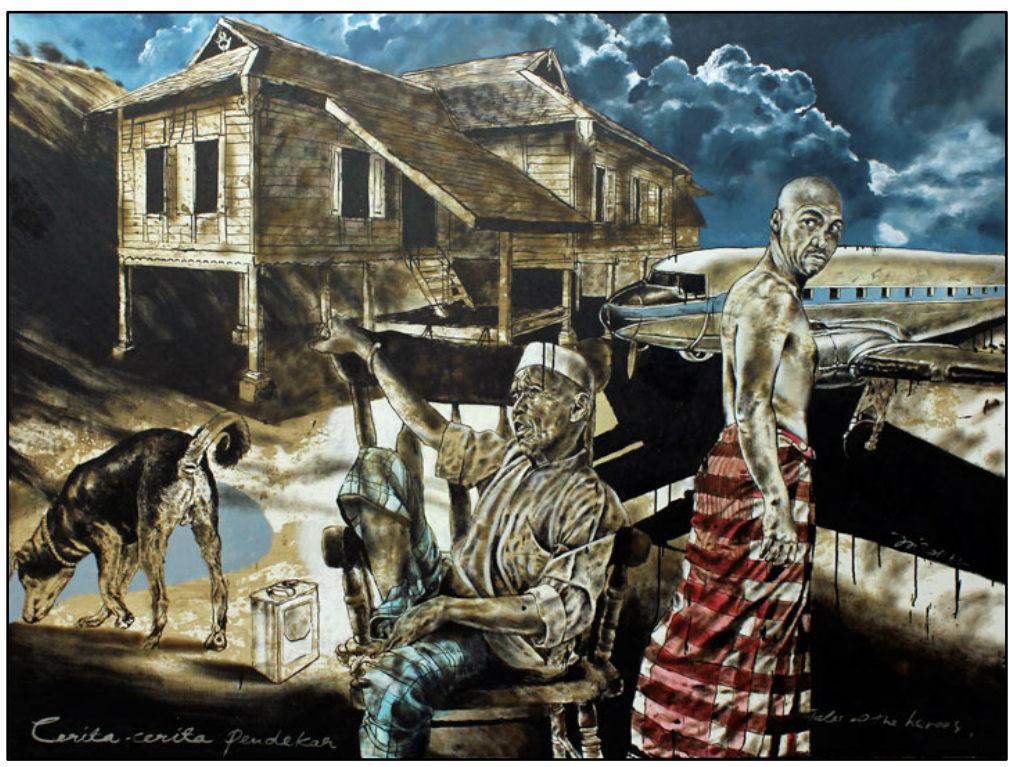

Figure 3: Jalaini Abu Hassan's Tales of the Heroes (2010), Acrylic and bitumen on canvas, $137 \mathrm{~cm} \times 183 \mathrm{~cm}$. Courtesy of Tyler Rollins Fine Art, New York.

(Source:

http://artasiapacific.com/Magazine/WebExcluszives/BangsawanKebangsaanJalainiAbu Hassan,2020)

\subsection{Edmund Feldman art criticism approach}

\subsubsection{Description}

Tales of the Heroes was produced by Jalaini Abu Hassan, using acrylic and bitumen paints on canvas, $137 \mathrm{~cm} \times 183 \mathrm{~cm}$. This artwork was a permenant collection of Tyler Rollins Fine Art, New York. 


\subsubsection{Analysis}

Based on the formalistic aspects, Jalaini preferred to express realism in his artworks where the whole subject such as Malay traditional home has repeated straight line to create the appearance and the shape of the house which made of wooden entirely. The perspective on the traditional house produced by this artist gave the three-dimensional effects which can be seen on the front of the house that has a main door staircase, the side that has windows and also on the roof of this traditional house, giving a more realistic effect in Tales of the Heroes. On the surface of the wood in the form of this traditional house produced by this artist also looked like a visible texture that can be seen in the eyes of art lovers but in the reality, it has a touch of texture on the wooden surface of this traditional house if observer sees it in the real situation.

Furthermore, the artist also painted a dog with a more realistic look using a tonal effect that gave the dark side effect on the dog's head with a clear lighting effect visible on the skin wrinkles of this dog. Generally, the artist managed to give a realistic soul to this animal created by Allah SWT. The artist also used cool colours that can be seen on the blue part of the sky mixed with a little white that has colour tone effect which can be felt and soothed the eyes of this modern painting art's fan.

At the same time, the artist also emphasized the use of warm colours such as red that can be seen on the surface of the kain pelikat worn by the figure of a shirtless man in Tales of the Heroes. In terms of appearance, it seemed to have straight and also curved lines for the artist to produce the look and the shape worn by the male figures who was shirtless above. Furthermore, the shape aspect can also be seen on the shoulders, the arms and the chest that exhibited the masculine characteristics of the male figure based on the above painting.

Another significant external aspect can be seen at the top of the Malay clothes worn by the man with a kopiah on his head. Wrinkles on the front of baju Melayu worn by the man with the kopiah looked more realistic with minimum lighting and expressed the dramatic effect. The artist also stressed the art elements such as the space between the traditional Malay house with the dog and also the two men.

In the meantime, the shape of the plane has also been emphasized in Jalaini's work by using cool and soothing colours such as blue and white. The body of this aircraft was also seen to have only half shape and appearance because the artist emphasized and focused on the appearance of the male figures and the physical aspects of the traditional house shape as the subjects of this painting. The lines used by this artist was a straight horizontal line and curved lines on the front of the plane body. The dog figure also represented the artist knew more regarding the concept of halal and haram in the Malay-Muslim community life which the artist has practiced in his life. Thus, this painting clearly represented that the artist 
adhered to the strong belief in the traditional Islamic medical work that is still practiced today.

\subsubsection{Interpretation}

More personal than political, Tales of the Heroes (2010) presented an intimate vignette of the artist's family heritage, depicting the artist and his father in Islamic attires in a Malay village house. In a number of his other paintings, the artist assumed the role of him and his father who were involved in the real-life Islamic spiritual healing grounding his visual identity in the Malay tradition. Being self-conscious of his function as the narrator, Jalaini Abu Hassan's self-portrait stands was slightly aloof and glanced down towards his father, observing rather than participating in the scene.

The work of this artist described the environment of the Malay villages in Malaysia, which is depicted in Figure 3 through his father and the artist himself. Besides that, the painting also described the atmosphere of the village using the element of clothes where his father was seen to be wearing baju Melayu and kopiah. Meanwhile, the depiction of Jalaini himself who was wearing kain pelikat as traditional clothes was an expression of their Islamic and Malay identities in the painting (Mohd, 1980). The painter also portrayed a traditional Malay house as the background subject in his painting in order to show his life within a Malay village and culture. In terms of colour, the artist used dull colours such as grey for the shape of the house and also the outfit of Jalaini Hassan reflected the situation where a Malay community is full of medium that depicted the Malay tradition of the day. Colours such as black, brown and red were also used in this painting. Abdul Malek (2019) believed that providing art opinions was half of the characteristic's functions in line with the community group requirements. The objects applied in the painting included a shirtless man wearing kain pelikat and his father who wore kopiah and baju Melayu. Such attire symbolized the environment of a typical Malay village while the two characters represented the cultural and the identity elements of the Malay community. In addition, the architecture and the design of the wooden house can be seen as an effort to maintain the Malay tradition.

In addition, the symbol of Malay and Islam were closely interlinked with each other as shown in this artwork where the man wearing kopiah indicated he practiced Islamic teaching. In addition, he dressed in the formal attire of a Malay-Muslim when going to pray and religious places. Not only that, the baju Melayu also was drawn representing Malays baju Melayu as it has 5 buttons. These 5 buttons illustrated the 5 National Principles (Rukun Negara) that are required and should be remembered by each Malaysian. The 5 principles of National Principles are Belief in God, Loyalty to the King and Country, Supremacy of the Constitution, Rules of the Law and lastly, Courtesy and Morality. 
The painting also indicated the artist was concerned about the Malay philosophy and cultural values established by the national ideology on August 31, 1970. This concept was in line with the National Cultural Congress that provided ideas and encouragement among artists to produce artwork representing the socio-culture of the Malay community. In addition to describing the philosophy of 5 buttons at the baju Melayu, it is also indicating the philosophy of the 5 Pillars of Islam which should be abided by all Muslims. That is, the first is to say two words of syahadah and fulfill His rights, the second is to perform the 5 times a day prayer, the third is to fast in the month of Ramadan, the fourth is to pay zakat and the fifth is to perform pilgrimage (Hajj) for those who afford. This artwork clearly show the Malay traditional shirt worn by the men also have significant Malay heritage symbols and also can not be separated based on the principles that must be adhered by every individual Muslim. These 5 Pillars of Islam are also important for each individual who live based on these 5 principals.

\subsubsection{Judgement}

In the creation of this artwork, many of the activities demonstrating the medium of a Malay village. The activity also exhibited a medicinal issue that usually happened in the Malay community such as traditional medical practitioner was referred to the modern Islamic context. In addition, the Malay community emphasized the lifestyle believes among the traditional Malay medicine practitioners. According to Din (2011), Islamic spiritual healing is an alternative medicine that focuses on the use of prayers adapted from zikr and verses of Islamic holy book, the Quran. Furthermore, the Malay medication is a legacy of the past, which is an alternative method of treatment that is dependent on the Al-Quran scriptures combined with the use of herbal plants in its medication process. This is because the Islamic medication also refers to the Islamic value in curing diseases in the Malay community. According to Abdullah et al. (2016), the practitioners of Islamic spiritual healing deal with a multitude of problems among the Malay society during that period of time.

The work of this artist showed many symbols of Malay tradition and culture such as the traditional Malay house and attires of the men which was baju Melayu that closely related to the philosophies of the National Principles and the Pillars of Islam which must be implemented in every Malay since childhood. Despite the full figure of the old man in the painting which was his own father, Jalaini also showed that he has knowledge on the MalayMuslims medication by pointing out the tradition of the Malay community for generations which trusted preachers and Masters who were expertise particularly in terms of religious practice of reading the Quran verses while practicing the Malay traditional medicine based on Islamic faith. Overall, the work of this artist managed to convey a message that has quite

profound meaning in the National Cultural Congress held in 1971. The painting of this artist was successfully produced by emphasizing the 
cultural aspects of the Malay tradition that has been inherited since the ancient times.

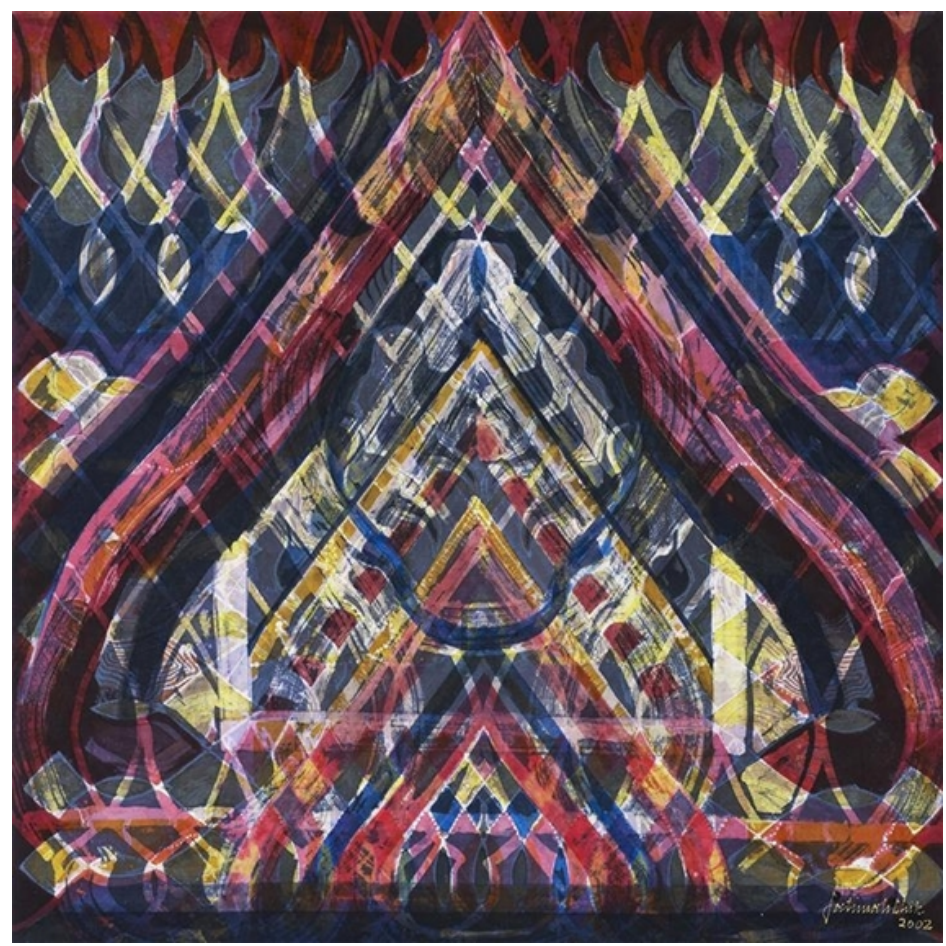

Figure 4: Fatimah Chik, Batik laid on canvas: Pohon Beringin, $122 \mathrm{~cm} \times 122 \mathrm{~cm}$, (2002) (Source:https://www.mutualart.com/Artwork/POHON-BERiNGIN/CBDEA9629325C9C4, 2020)

\subsection{Edmund Feldman art criticism approach}

\subsubsection{The Description}

Pohon Beringin was produced by Fatimah Chik in the year 2002. The size was $122 \mathrm{~cm} \times 122 \mathrm{~cm}$ and the medium that artist used was batik laid on canvas. This artwork was in her own self collection catalogues before it was sold to an art collector.

\subsubsection{The Analysis}

The analysis of the artwork was based on the Fatimah Chik's artwork as in the figure above which has been fully produced using batik technique and created on canvas. In terms of formalistic analysis that can be observed on the artist, Fatimah Chik emphasized the technique of brush then applied on the surface of her batik painting with quite thick line strokes. The result of producing artworks using this style of painting indicated that she was an aggressive person and cared about the neatness in her batik painting artwork entitled Pohon Beringin. Additionally, the colours used by this artist applied basic colours such as blue, yellow, red and purple. In terms of the colour used, the artist mixed both types namely warm and cool colours. 
In terms of the style produced, the artist of this batik painting used a very spontaneous abstract style. This is because every touch of brush used by this artist is very neat and rapid and it looked organized even though it was produced using a relatively thick brush technique.

From the colour tone used, this painting has a relatively subtle colour tone value and it looked meticulous with the placement of basic colours such as blue, yellow, red and purple. In terms of the art of intertwine, this artist also created rough and thick lines but still looked organized and neat. At the same time, the result of this visible intertwine made Fatimah Chik's artwork has its own value. The artist tried to create repeated thick lines to show the shape of a triangle that gave a symbol to form Pohon Beringin that was often used by the Malay community as it has its own philosophy. Although the artist used the abstract style, the appreciation of the visual arts seemed very clear with the significant meaning of the Malay symbols.

From the aspect of the principle of art, the artist also applied many principles of art that have their own identities. From the aspect of the balance and comparison rates, this artwork was also quite symmetrical and balance. In addition, the movement element can also be seen on the repeated thick and rough lines on the background of this banyan tree which gave the rhythm effect. However, the lines used by this artist also filled the whole space in her batik paintings. The artist also emphasized the affirmation aspect her work which can be seen clearly from the main shape such as the triangular shape and the use of basic colours. The affirmation of the red colour also reflected the warm colour generated from the repeated line forming a triangular symbol that reflected the Malay heritage symbol of this banyan tree.

From other formalistic aspects, the background colour of this painting used blue colour which gave the dark effect on the background of this batik painting. At the same time, the artist used bright and contrast colours such as red and purple on the triangular lines that gave the symbol of this banyan tree. The union value can also be seen in the middle of this batik painting that looked the same on both right and left sides of this batik painting by Fatimah Chik. Furthermore, the movement effect can be seen on the part of the yellow curved line as if to give a fairly clear movement effect on the background of the batik painting of this banyan tree artwork.

Overall, the artist managed to produce a painting by applying a satisfactory external aspect. The colours chosen by this artist were clearly visible through the layer by layer technique of 4 different colours in this batik painting art. The triangular image was clearly seen as the dominant motive or subject in this banyan tree painting artwork.

\subsubsection{The Intrepretation}

From the past history, Fatimah Chik's artworks were always related and relevant to the Malay community's philosophical symbols. Based on the 
analysis in Pohon Beringin, this artwork was very related to the opening performance of Wayang Kulit or also called as Buka Panggung. This artwork also clearly gave the historical value of the performing arts in preserving the richness of art symbols in the Malay community. This is because Wayang Kulit performances have also been recognized by the United Nations Educational, Scientific and Cultural Organization or also known as UNESCO.

This artist also conveyed her batik paintings in her deep intrinsic meaning regarding the symbol related to the Malay culture as the national heritage. It also included Kelantan as one of the states in Malaysia that practiced the performing arts such as Wayang Kulit and Dikir Barat as the Malay heritages. Although the Malay community has various arts and cultures, it is undeniable that the art performances which are Wayang Kulit and Dikir Barat, are still being played and passed down to the young generation. In Malaysia, Wayang Kulit has four types of performances that are commonly performed in some places. The Wayang Kulit played includes the Malay Wayang Kulit, the Wayang Kulit Gedek, the Wayang Kulit Purwa or also called the Javanese Wayang Kulit, and also the Kelantanese or the Siamese Wayang Kulit.

All these Wayang Kulit are the symbols from the deep meaning of the banyan tree which was always used as the motive in the performance art of Wayang Kulit. Generally, the banyan tree is a symbol of Wayang Kulit that gives a lot of meaning in delivering a message through Wayang Kulit performances played by local Malay community. This also gives a clear message from the effects of the communication expressed by the Wayang Kulit performance artist as a presentation of communications related to the life and the example of living arrangements among the Malay community in this era.

The banyan tree is the most dominant figure motive especially in Wayang Kulit set among the Malay community. It also can be seen in Pohon Beringin by Fatimah Chik who gave the symbol of heart shape through the triangle shape as can be seen in Figure 4. The Malay community also believes that the Pohon Beringin motive itself originated from banyan trees that live and grow in Malaysia since our ancestral era. At the same time, as an ordinary human being living based on the Islamic principles, it is not wrong for the artist to have flora motive as an inspiration in creating artwork as flora is a perfect creation by Allah SWT that has many benefits and advantages to human life as caliphs on this earth. This is because the Malay philosophy and Islam itself can not be separated as long as it does not violate the Islamic teachings. Therefore, it is clear that the art of Wayang Kulit not only important as the medium of communication but also the interaction medium between the human relationship with Allah SWT and also the environment.

In addition, the intrinsic meaning of banyan tree in the Malay culture can also be associated with the traditional Malay film like Bawang Putih 
Bawang Merah which was published in 1959, played by the main actress and actor, namely Latifah Omar and Mustapha Maarof. In the whole film, Bawang Putih Bawang Merah showed Latifah Omar singing a song entitled Pohon Beringin in a sad tone.

The songlyrics of the Bawang Putih Bawang Merah Malay film is written as follows:

\author{
Pohon beringin tegaknya tinggi \\ Kalau rendah menyapu bumi \\ Penghibur aku \\ Menolong aku \\ Bertiuplah oh angin bayu \\ Laju..laju..buaiku laju \\ Akulah anak yatim piatu \\ Laju..laju.. \\ Buaiku..laju. \\ Pohon beringin daunnya rendang \\ Akar berjalur cecah ke bumi \\ Hatiku ingin hidup gemilang \\ Nasib malang suratan diri \\ Hidup aku tidak beribu \\ Akulah anak yatim piatu \\ Pohon beringin tumboh sendiri \\ Tempat berayun, menghibur lara \\ Sungguh la sudah membawa diri \\ Tiada siapa yang kasih mesra \\ Laju..laju..buaiku laju \\ Akulah anak yatim piatu
}

Through the lyrics of the song that presented in the movie, it is clear that the symbolic meaning of the banyan tree existed in the Malay film by watching Latifah Omar was so into the character and acted as Bawang Merah in the black and white movie which indicated the Malay film was produced in the 1950s did not have coloured movie yet.

\title{
4.2.4 The Judgement
}

This batik painting artwork produced by this artist was based on the National Cultural Congress which clearly exhibited on the appearance elements in particular such as the triangular shape that has been dominated like this batik painting of the banyan tree. Furthermore, the triangular shape also represented various types of Wayang Kulit in Malaysia that symbolized the Malay community philosophy values that can convey positive message through verbal communication among the community since earlier generations and up till now. Besides, the impact of National Culture Congress has opened Fatimah Chik's eyes about the 
symbols of Malay through this important artwork related to social life, status and glory life of the Malays themselves.

Generally, as a result of this artwork, Pohon Beringin also upheld the Malay civilization itself. Although Wayang Kulit in Kelantan has its own influence from the Java and the Pattani communities from the Southern Thailand, at the same time, this Kelantanese Wayang Kulit has positive contents in terms of the presentation itself. Similarly, the symbol of Malay philosophy in Fatimah Chik's Pohon Beringin could not outcast the Islamic elements and principles, which were the main cores of her painting.

Among the important characters in the Kelantanese Wayang Kulit were Hanuman, Sri Rama, Sita Dewi, Maharaja Rawana and Laksamana. Although the language used was in the Kelantan dialect, if the artists were asked to explain the issues presented in the show, they were still able to deliver the message that contained the main values of their performances in the Malay language. The aspect of Malay literature were also considered as the Malay symbols in the Fatimah Chik's Pohon Beringin as the artist took the ideas from an old Malay movie, Bawang Putih Bawang Merah that exposed the credibility of many symbols of the Malay community and also through Pohon Beringin song sung by Latifah Omar in the film.

\subsection{Discussion}

From the results of the data collection through tours in the artists' galleries, researchers obtained detailed information through the Malay culture symbols which are rarely applied in paintings especially in this era. Also, by associating with the artists of National Culture Congress can expose us with the Malay culture symbol that consistently being left behind in the present generation. Some of the exhibition catalogues have been accepted by the researchers, including some from the famous curator such as Faizal Sidik and also art teacher, Omar Adzran which they have experience in the field of socio-cultural in more detail.

In the $21^{\text {st }}$ century, many artists have been inspired and refined the idea of the old Malaysian story in creating the significant Malay symbols. Jalaini Abu Hassan and Fatimah Chik have revealed a number of features or elements of the Malay community that have a positive impact on their overall works. Jalaini Abu Hassan disclosed MalayMuslim medical knowledge, philosophy of Baju Melayu and kain pelikat. Furthermore, Fatimah Chik also has the advantage of associating her artwork with Malay movie Bawang Putih Bawang Merah casted by Latifah Omar and some other actors. Her artwork also adapted banyan tree in her Pohon Beringin batik painting. Kelantanese Wayang Kulit and Pohon Beringin also adapted banyan tree as the flora motives that significantly provided strong evidence related the origin history in Malay philosophical

elements that has always been associated with diverse motives in the Malay community. 


\subsection{Conclusion}

The findings of this study concluded that the cultural and the local values are among the consistent and the current themes that are still accepted in the production of artworks among Malaysian painters. The cultural elements of the Malay community can be seen in the works of Jalaini Abu Hassan and Fatimah Chik. After the National Cultural Congress (NCC) in year 1971, Malaysian painters continued to imply cultural, brush technique, Malay hand-drawn batik, Malay film Bawang Putih Bawang Merah, Kelantanese Wayang Kulit and abtsract textiles style. In her Pohon Beringin, Fatimah Chik clearly presented her artwork which based strongly on the Malay symbols. On the other hand, Tales of the Heroes exhibited men wearing baju Melayu depicted the five Pillars of Islam and the National Principles that must be obeyed by all Muslims or Malaysians. Other than that, based in the intrinsic meaning in his Tales of the Heroes, Jalaini Abu Hassan and his father's figures believed that the traditional Islamic medicinal knowledge that were practiced by the Malay community since ancestral era were still being practiced to deal with a multitude of problems among the Malay society during that period of time as there were conventional medicine. The Malaysian artist should aware and consistently committed to incorporate the Malay symbols and local values in creating their artworks. The siginificance of the study can be stated as follows: emphasized the uniqueness of the painting art by local painters such as Jalaini Abu Hassan and Fatimah Chik who practice Eastern Philosophy culture; showed high heritage values particularly the art of painting Malay philosophy such as Pohon Beringin by Fatimah Chik and Tales of the Heroes by Jalaini Abu Hassan; and identified the intrinsic meaning behind the paintings of Pohon Beringin and Tales of the Heroes which associated with the Malay symbols in the Malays community.

\subsection{Recommendation}

Following this study, it is suggested that these values and symbols should continue to be preserved in order to avoid it to be obsolete and dismissed by the current modernity. In this regard, both artists and academicians should work together to preserve the value of the Malay cultural heritage to sustain its prominence not only among the younger generations but also within the artworks produced in this future. The researchers also encourage Malaysian painters to sustain their supports towards the National Cultural Congress (NCC) in 1971 as part of the effort to preserve and to conserve the national heritage in their artworks for the benefits of the future generations.

\subsection{Acknowledgement}

The authors would like to thank Mohamad Hadzal Kamarulzalis for his guidance in completing this study. 


\section{References}

Amin ,M. N \& Rahman,N.A.A, (2013). Rebranding through Names: A New Revolution in the Malays identity Identification. Academic Journal of Interdisciplinary Studies. 9(2).264273.

Arif, H.B.A., Noor, A.I.B.N., Abdullah,N.B., \& Hamzah,M.J.B (2019). Herbaceous Plant as Malay Carver's Motif Inspiration. International Journal of Technical Vocational and Engineering (IJTVET),1(1) e-ISSN:2710-7094.

Abdul Malek,S.N., (2019). Biografi, Naratif: Penghasilan Makna Melalui Catan, Kupas Seni: Jurnal Seni dan Pendidikan Seni,4. Universiti Pendidikan Sultan Idris.

Ali ,Z(1989). Seni dan Seniman: Esei-esei seni halus: Kuala Lumpur. Dewan Bahasa dan Pustaka.

Ahmad,S.H. (2020). Elemen budaya dalam karya seni catan Malaysia: satu tinjauan. idealogy, 5(1), 157-164.

Amran, K (,2002). Perkahwinan Melayu, Kuala Lumpur. Dewan Bahasa Dan Pustaka.

Aziz Deraman, A. (2002). Tamadun Melayu dan Pembinaan Bangsa Malaysia: Kuala Lumpur, Dewan Bahasa dan Pustaka.

Benecke, D. W. (1989). Cultural Life in the Federal Republic of Germany, Germany, Bonn Inter Nationes Bonn.

Denel,B (1979), A Method For Basic Design And Creativity,Ankara :METU , Faculty Of Architecture

Davies, P. H. J. (2001). Identity, Continuity and Silat: Some Dilemmas For Cultural Continuity In A Time Of Rapid Change, paper presemted at Symposium Kebangsaan Masyarakat Malaysia: Isu Dan Cabaran Abad Ke-21 Pada 22-24 Julai Di Fakulti Sastera Dan Sains Sosial, University Malaya, Kuala Lumpur.

Din, H. (2011). Siri Pengajian Islam: Rawatan Penyakit Akibat Sihir) Series Of Islamic Medicine Study: Healing Of Ailments Due To Black Magic (Sihir) Malaysia: Islamic Medicine And Welfare \& Darissyifa Cooperative Limited

Feldman, E.B. (1967). Arts as image and Idea, Prentice Hall, Inc Englewood Cliff, New Jersey

Hasbullah, W. M. D. W. (2018). Rahman,M.A: Konsep Tempur Seni Gayong dan inovasi silat Melayu. Jurnal Pengajian Melayu, 29(1), 262-285.

Haji Mohamad Noh. , L.M (2013). Manifestasi pandangan dunia Melayu dalam rupa dan jiwa seni catan wanita Melayu tahun 1970-1990/Liza Marziana Haji Mohammad Noh.proceeding penyelidikan pemikiran dan kepimpinan Melayu (IMPAK). 
Kari, R., Samin, A., \& Legino, R. (2018). The Sustainability's Motif and Design of Fauna in Malay Block Batik. In International Conference on Social Sciences, Humanities, Economics and Law. European Alliance for Innovation (EAI).

Md Nawawi, N. A. A., Legino, R. N. H., Ahmad, N., \& Ismail, H. (2015). The Nature of Malay Songket Textile Patterns. Bussiness and Management Quaterly Review, 2/3(6), 41-56.

Noh, L.M.M., Sharif,N.H.M., Hassan,S.A., Wahida,A., \& Pattanachoti,0.(2020). An Art Appreciation Approach On Analyzing Form And Content Of Malay Culture Of Symbols in Malaysian Painting. International Journal of Academic Research in Business and Social Sciences, 10 (7), 553-538.

Musa, N. N., \& Ramli, H. (2014). Identiti Melayu dalam Catan Syed Ahmad Jamal. KUPAS SENI: Jurnal Seni dan Pendidikan Seni, 2.

Najri,P (2011). Apresiasi Dan Kritikan Karya Haron Mokhtar, Universiti Pendidikan Sultan Idris, Academia.edu

Noh, L. M. M., Haron, H., Samian, A. L., Hasan, A. R., \& Dolah, J. (2015). Analisis formalistik dalam memaknai simbol budaya melayu abstrak. International Journal of Creative Future and Heritage (TENIAT), 3(2), 49-72.

Rashid, N.A (2005). Nilai Kesantunan Dalam Konteks Sosiobudaya Masyarakat Melayu, Jurnal Pengajian Melayu, 15.1 (2005): 232-253.

Ramli, H., Said, T. S., \& Jamaldin, S. S. (2019). Eksperimentasi Teknik Tritik Dalam Pembelajaran Mereka Corak Tekstil Batik. KUPAS SENI: Jurnal Seni Dan Pendidikan Seni, 5. Retrieved from https://ejournal.upsi.edu.my/index.php/JSPS/article/view/2268

Samad Ahmad, A. (2003) Sulatus Salatin Sejarah Melayu: Edisi Pelajar, Kuala Lumpur, Dewan Bahasa dan Pustaka.

Subiyantoro,S \& Zainnuri,H(2017). Gunungan Wayang Sadat: The Study of Its Religious Values and Its Relevance in Fine Art learning in High Schools.Pertanika Journal Social Sciences and Humanities. 25(s).273-280

Silah, S, Basaree,R.O., Isa,B,\& Redzuan,R.S. (2012). Tradition and Transformation; the structure of Malay woodcarving motifs in craft education. International Conference on University Learning and Teaching, Procedia-Social and Behavioral Sciences, 90, 823-831

Wong, F. E. C., \& Yousof, G. S. (2018). The Visual Elements in the Pohon Beringin Figure of the Kelantan Shadow Play. Malaysian Journal of Performing and Visual Arts, 4(1), 63-78.

Zainuddin,N., Aris,A., Tulos,N., \& Zakaria,M.H. (2020). The Evolution of Malay Bride's Traditional Wedding Attire in Peninsular Malaysia, Environment Behaviour Proceedings Journal, 5 (SI1), p. 239-247. 